Volume 7 No. 3, September 2020

Nationally Accredited Journal,

Decree No. B/4130/E5/E5.2.1/2019

\title{
Bank Credit Agreement with Warranty of Decree Appointment of Civil Servants
}

\section{Chairul Insani Ilham*)}

*) Civil Servants in the Ministry of Transportation Indonesia, Poltektrans SDP Palembang, Email: chairul@poltektranssdp-palembang.ac.id

\begin{abstract}
The relationship between bank and the customer in the credit agreement with the guarantee of Decree Appointment of Civil Servants begins with the arrival of the customer at the Bank on working days and hours to provide complete requirements and fill in loan application forms that can be taken immediately. Then proceed with the bank conducting a field survey to ensure that the debtor is indeed a civil servant according to the data written by the debtor and an assessment of the potential debtor's ability to pay off his debt. And it ends with the disbursement of credit funds by banks to debtors for the loan ceiling of $60 \%$ of the employee's net salary according to the class/rank owned by the customer/prospective debtor. This research uses an empirical juridical approach. This method is used to obtain the truth in discussing existing problems and to see the application of a rule of law in society. The analysis is carried out descriptively which will describe, describe and reveal how the actual implementation of the credit agreement with the guarantee of Civil Servant Decree at Bank. The efforts of the banking sector to secure credit with the guarantee of a Decree Appointment of Civil Servants who are problematic are based on fulfilling the requirements and completeness of the identity data of the prospective debtor, the second is the provision of a period for debt repayment where the period does not exceed 5 years, and finally, the submission of a guarantee for the Decree of the Appointment of Civil Servants, all of which must be original. If the debtor is a mutation, it is requested or confirmed in advance to the office/agency where the debtor works to transfer funds against credit repayments to the Bank.
\end{abstract}

Keywords: Agreement; Credit; Civil Servants.

\section{INTRODUCTION}

Credit in banking activities is the most important business activity ${ }^{1}$, because the largest income from bank business comes from income from credit business activities, namely in the form of interest and fees. According to the provisions of Act No. 7 of 1992 concerning Banking, whereas in Article 1 paragraph (11) what is meant by credit ${ }^{2}$ :

"Is the provision of money or an equivalent claim, based on a loan agreement between the bank and another party which requires the borrower to repay after a certain period of time with interest".

\footnotetext{
${ }^{1}$ Chusna, Amalia., \& Hafidz, Jawade. (2019). The Role of the Notary in the Credit Agreement with Mortgage Guarantee (Case Study in the Bank Tabungan Negara (Persero) Tbk). JURNAL AKTA: Vol. 6, No. 4, 719-726. Retrieved from http://jurnal.unissula.ac.id/index.php/akta/article/view/7668

${ }^{2}$ Article 1 paragraph (11) Act No. 7 of 1992 concerning Banking
} 
In credit, an important element is the existence of trust and the other is the nature or consideration of mutual help. In terms of creditors, the most important element in current credit activity is to take advantage of their capital by expecting a return on performance, while for debtors it is assistance from creditors to cover their needs in the form of achievements given by creditors. It's just that between the achievement and the return of the achievement there is a period that separates it, so there is a certain grace period. This condition results in a risk, in the form of uncertainty in returning the achievements that have been given, therefore a guarantee is needed in the provision of credit ${ }^{3}$.

To reduce this risk, according to the explanation of to Act No. 7 of 1992 concerning Banking, it is explained that the guarantee of credit extension in the sense of confidence in the ability and ability of the debtor to pay off his debt as agreed is a factor. Important that must be considered by the bank. To obtain this assurance before granting credit, a bank must make a careful assessment of the character, ability, capital, collateral and business prospects of the debtor. Given that collateral is one of the elements of the credit guarantee, if based on other elements there is confidence in the debtor's ability to repay his debt, collateral can be in the form of goods, projects or collection rights financed by the credit concerned ${ }^{4}$.

In the context of credit, the term collateral is often interchanged with the term collateral. The definition of guarantee is as confirmed in the provision of credit in accordance with Article 2 paragraph (1) Decree of the Board of Directors of Bank Indonesia Number 23/69/KEP/DIR dated February 28, 1991 concerning Guarantee of Credit, then that guarantee is a conviction. Bank on the ability of the debtor to pay off the credit as agreed. Thus examining the meaning of the terms used by Prof. Soebekti, with a guarantee as below, according to Djumhana, actually must use the term collateral. The ideal guarantee can be seen from $^{5}$ :

a. Can easily help obtain credit by parties who need it;

b. Does not weaken the potential (strength) of the credit recipient to carry out (continue) the business;

c. Provide assurance to creditors in the sense that they are easy to cash in to pay off debtors' debts.

Furthermore, regarding the credit guarantee, seen from its function, it is divided into two, namely ${ }^{6}$ :

a. Collateral based on the bank's confidence in the character and ability of the customer/debtor to repay credit, with funds originating from credit-financed businesses, which is reflected in the cash low of the customer/debtor or better

\footnotetext{
${ }^{3}$ Saputri, Anindia I., \& Witasari, Aryani. (2020). Notary Role In Making The Deed Of Murabahah Financing On Islamic Bank (Review On Financing Agreement In Islamic Bank Of Central Java). JURNAL AKTA: Vol.7, No. 2, 229-236. Retrieved from http://jurnal.unissula.ac.id/index.php/akta/article/view/7874

${ }^{4}$ Suciani, Fiana Z., \& Witasari, Aryani. (2018). Implementation Of Mudharaba Agreement In PT. Bank Tabungan Negara (BTN) Tbk. Sharia Business Unit (SBU) Branch Of Semarang. JURNAL AKTA: Vol. 5, No. 4, 865-870. Retrieved from http://jurnal.unissula.ac.id/index.php/akta/article/view/3721

${ }^{5}$ Hasanuddin, Rahman. (1995). Aspek-aspek hukum Pemberian Kredit Perbankan di Indonesia. Bandung: Citra Aditya Bakti, p. 59-60

${ }^{6}$ Iswardono. (1999). Uang dan Bank. Yogyakarta: Liberty, p.34
} 
eISSN : 2581-2114, pISSN: 2406-9426

known as the first way out. To obtain this confidence, banks must conduct analysis and evaluation of the character, capability, capital and prospects of the debtor.

b. Collateral based on the liquidity of collateral/second way out if in the future the first way out cannot be used as a means of repaying credit.

In banking practice in general, the credit agreement has been made in a written standard or standard form, and in a blank or form ${ }^{7}$. The form is given to each credit applicant, the contents of which are not discussed but after being read by the credit applicant, the bank only asks for the opinion of the customer whether or not they can accept the terms in the form ${ }^{8}$, while the blanks in the credit agreement are like the size loans, the amount of interest, the credit period, and the purpose of using the credit are things that cannot be filled in before there is agreement from both parties. The contents of a predetermined credit agreement in a certain form that has been standardized show us that the credit agreement in banking practice is a standard agreement ${ }^{9}$.

In dealing with such lending practices, a prospective customer generally cannot do other than agreeing to it, because if he does not approve it means that his credit application has failed or credit is rejected, while he really needs the credit. This collateral shows a change in the productive market (real sector) to consumptive market. This change is against the backdrop of conditions in the real sector which are still unable to operate normally. So the Bank considers the real sector still has risks, especially in this sector that is driven by large companies ${ }^{10}$.

Even so, credit risk without collateral cannot be taken lightly, cumulatively, the level of risk remains high, moreover the requirements are very simple and generally no collateral at all (collateral according to the meaning of the Banking Law) ${ }^{11}$, although in practice a "guarantee" is still required, however The guarantee is not a property, either movable or immovable property, for example, guaranteed by a Decree of the Appointment of Civil Servants. This is even more so with the economic and security conditions that greatly affect it, for example with the impact of the increase in fuel oil (BBM) and also the impact of the issue of an increase in the basic electricity tariff (TDL). This is what creates obstacles in the debtor's efforts to pay off his debt and if there is bad credit in the future.

\footnotetext{
7 Adigita, Monicha R., Ma'ruf, Umar., \& Witasari, Aryani. (2019). The Role and Protection of Laws to Notary Related To the Dispute That Made Between the Parties. JURNAL AKTA: Vol. 6, No. 4, 783-788. Retrieved from http://jurnal.unissula.ac.id/index.php/akta/article/view/7631

8 Ferdiyanti, M. Indah Verena., Purnawan, Amin., \& Soegiyanto. (2019). Setting the Effectiveness of Law Position and Code Notary to the Quality of Performance. JURNAL AKTA: Vol. 6, No. 4, 797-804. Retrieved from http://jurnal.unissula.ac.id/index.php/akta/article/view/7887

${ }^{9}$ J, Satriyo. (1993). Hukum Jaminan, Hak-hak Jaminan Kebendaan. Bandung: Cira Aditya Bakti, p. 214

${ }_{10}$ Putra, Edy. (1986). Kredit Perbankan Suatu Tijauan Yuridis. Yogyakarta: Liberty, p. 329

${ }^{11}$ Harjanto, Fery., \& Gunarto. (2018). Effects Of Creation Deed of Sale and Purchase of Land Which Does Not Match Procedure of Making Land Deeds. JURNAL AKTA: Vol. 5, No. 4, 857-864. Retrieved from http://jurnal.unissula.ac.id/index.php/akta/article/view/3718
} 
eISSN : 2581-2114, pISSN: 2406-9426

\section{METHODS}

The approach method used in this research is juridical-empirical. The juridical-empirical approach method, which is an approach that examines secondary data first and then continues to conduct primary data research in the field ${ }^{12}$. This juridical approach method is used to analyze various laws and regulations relating to the implementation of credit agreements guaranteed by the Decree of the Appointment of Civil Servants. Meanwhile, the empirical approach is used to analyze the law not merely as a normative set of laws and regulations, but the law is seen as the behavior of the community (Civil Servants) that is symptomatic in people's lives ${ }^{13}$.

\section{RESULTS AND DISCUSSION}

It is very important that the writer wants to know the implementation of the credit agreement, and to find out the efforts of the bank/creditor as security against nonperforming loans and the execution of credit without collateral if one of the parties is in default ${ }^{14}$.

\subsection{Types of Credit Agreements}

In banking practice in Indonesia, legally formal there are 2 types of credit agreements used by banks in releasing credit:

a. Deed/underhand credit agreement;

Is a loan agreement by a bank to its customers that is only made between them (creditors and debtors) without a notary

b. Deed/notarized credit agreement (authentic);

Is an agreement made by Notary in extending credit to customers made before a Notary.

\subsection{Credit Agreement as Standard Agreement}

In banking practice, each bank has provided a credit agreement form or blank. The form is presented to each credit applicant whose contents are not discussed but after being read by the applicant, the bank only asks the prospective customer's opinion, whether or not they can accept the terms stated in the form. While things that are blank in the form, such as the amount of the loan, the amount of interest, the purpose for which the credit is used, and the credit period, are things that cannot be filled in without the agreement of both parties ${ }^{15}$.

The characteristics of a standard agreement are as follows:

12 Hadiri, Nawawi. (2002). Metode Penelitian Sosial. Yogyakarta: Gajah Mada University Press, p.92-93

${ }^{13}$ Moleong., Lexy. J. (2005). Metodologi Penelitian Kualitatif Edisi Revisi. Jakarta: PT Remaja Rosdakarya, p. 67-68

${ }^{14}$ Widyawati, \& Handoko, Widhi. (2018). The Notary Role / PPAT in Improving Legal Awareness Society to Perform Registration Rights to Land Based on Government Regulation No. 24 of 1997 on Land Registration. JURNAL AKTA: Vol. 5, No. 4, 975-980. Retrieved from http://jurnal.unissula.ac.id/index.php/akta/article/view/4127

15 Nofita S., Putri, Chalim, Munsharif A., \& Setyawati. (2020). Legal Protection Against Substitute Notary in Semarang Based on Act No. 2 of 2014 Amendment Act No. 30 of 2004 concerning Notary. JURNAL AKTA: Vol.7, No. 2, 195-200. Retrieved from http://jurnal.unissula.ac.id/index.php/akta/article/view/7901 
a. The contents or conditions agreed have been determined unilaterally;

b. The community was completely unable to determine the contents or conditions that were agreed upon;

c. The community is motivated by the need to be forced to accept the agreed contents or conditions, so that if they later change the contents or conditions, they cannot;

d. The contents or conditions that have been agreed upon have been prepared in advance. This credit agreement contains weaknesses, especially in connection with Article 1320 jo 1338 of the Civil Code, because the credit agreement does not contain an agreement in the broadest sense of both parties, but only onesidedly. Meanwhile, the petitioner in giving the agreement is only fictitious. Thus the credit agreement does not only contain weaknesses but also deviates from the principles contained in Article 1320 jo 1338 of the Civil Code ${ }^{16}$.

\subsection{Guarantee in the form of a Decree Appointment of Civil Servants}

Lending to the public by banks often collides with the absence of collateral in the form of collateral owned by prospective debtors. Facing this lack of collateral, banks as lenders responded by making offers to civil servants in the form of credit offers without the inclusion of collateral ${ }^{17}$.

Furthermore, regarding the credit guarantee, seen from its function, it is divided into two, namely:

a. Collateral based on the bank's confidence in the character and ability of the customer/debtor to repay credit, with funds originating from credit-financed businesses, which is reflected in the cash low of the customer/debtor or better known as the first way out. To obtain this confidence, banks must conduct analysis and evaluation of the character, capability, capital and prospects of debtors;

b. Collateral based on the liquidity of collateral/second way out if in the future the first way out cannot be used as a means of repaying credit.

In this credit, there is a general guarantee as stated in Article 1131 of the Civil Code, the bank is quite confident in the credibility of the prospective debtor. This is also stated in the explanation of Article 8 paragraph (1) of Act No. 10 of 1998 that "... guarantees for providing credit or financing based on Sharia Principles in the sense of confidence in the ability and ability of the debtor customer to pay off their obligations as agreed upon are important factors that must be considered by the bank". According to Soebekti ${ }^{18}$, the Civil Code recognizes three types of goods, namely movable property, fixed property, and bodily goods (which means receivables, billing or claims).

\footnotetext{
${ }^{16}$ Wahyuni, \& Ma'ruf, Umar. (2020). The function of the Notary / PPAT In filing process Acquisition of Land Rights To Interests Investment in Regional Autonomy Era Based on Act No. 25 of 2007 concerning Foreign Investment. JURNAL AKTA: Vol.7, No. 2, 189-194. Retrieved from http://jurnal.unissula.ac.id/index.php/akta/article/view/7965

${ }^{17}$ Arrohim, Mohammad B., \& Wahyuningsih, Sri Endah. (2020). Analysis of Judicial Application of Criminal Penalty Against Notary / Land Deed Officials Conducting Making Crime of the Fake Authentic Deed in State Court of Semarang. JURNAL AKTA: Vol.7, No. 2, 183-188. Retrieved from http://jurnal.unissula.ac.id/index.php/akta/article/view/7891

${ }^{18}$ Ibid.
} 
eISSN : 2581-2114, pISSN: 2406-9426

In Article 509 Book II, part four of the Civil Code, it is stated that movable property is ${ }^{19}$ :

"Movable property due to its nature is something that can move by itself or be moved."

According to Article 1150 of the Civil Code Book II of the Civil Code, the guarantee institution that accompanies a movable object is a pawn, namely:

"Pledge is a right obtained by a creditor for a movable property, which is handed over to him by the debtor, or by his proxy as collateral for his debt, and which gives the creditor the authority to take settlement of the credit from said item in advance of other creditors, with the exception of selling costs. As executor of decisions on claims regarding ownership or control, and the cost of salvaging said goods that were handed over as a pledge and which must be prioritized. "

Pawning is a guarantee by controlling the object and for creditors it will be safer because it is easy to transfer the movable property in the sense that it is sold at auction if the debtor defaults, although it is easy to change its value. This, if connected with the Decree of the Appointment of Civil Servants, is not included in movable objects and is not a pledge object ${ }^{20}$.

Another form of guarantee is insurance, in connection with this credit agreement there is no element of coverage in it, because there is no third party as guarantor of the receivables. In this credit agreement the treasurer is only the party authorized to deduct wages and payments to the bank as debt payments, not as the guarantor.

The bank emphasizes more on the element of trust in providing credit with a guarantee of a Civil Servant Decree. From these elements, it can be seen that the bank continues to use the principle of prudence and the principle of knowing the customer, where the debtor as a civil servant always maintains and does not damage his credibility ${ }^{21}$.

The terms and procedures mentioned above are the application of know your customer principles in accordance with Bank Indonesia Regulation Number 3/10/PBI/2001 concerning Application of Know Your Customer Principles. Application of Know Your Customer Principles by Bank in accordance with the provisions of Article 2 paragraph (2) letters $a$ and $b$ of Bank Indonesia Regulation Number 3/10/PBI/2001 which does not specify the procedures for the application of these principles. In applying Know Your Customer Principles as referred to in a Bank Indonesia Regulation, Banks are required to stipulate ${ }^{22}$ :

a. customer acceptance policy;

b. policies and procedures for identifying customers.

Based on the aforementioned provisions, it is known that any commercial bank may establish policies to be stipulated under the Know Your Customer principle, provided

${ }^{19}$ Fuditia, Megacaesa., \& Mashdurohatun, Anis. (2020). Protection Against Recipients Notary Deed That Allegedly Protocol To The Legal Issue In Semarang. JURNAL AKTA: Vol.7, No. 2, 177-182. Retrieved from http://jurnal.unissula.ac.id/index.php/akta/article/view/7888

${ }^{20}$ Ibid.

${ }^{21}$ Op.Cit.

22 Jaya, Hendro K., \& Purnawan, Amin. (2020). Review Of The Implementation Process Of Completion Of Juridical Code Violations Of Notary In Kendari. JURNAL AKTA: Vol.7, No. 2, 169176. Retrieved from http://jurnal.unissula.ac.id/index.php/akta/article/view/7881 
eISSN : 2581-2114, pISSN: 2406-9426

that the stipulated policies provide confidence in the customer's ability to repay their debts. This principle can be carried out by means of an assessment system of the character, ability, capital, and business prospects of the debtor customer known as The $5 C^{\prime}$ 's of Credit Analysis which is a measure of the ability of the credit recipient (debtor) to repay the loan, namely ${ }^{23}$ :

a. Character

What is meant by character here is the personality, morals, and honesty of the credit applicant. Whether he can fulfill his obligations properly, arising from the credit agreement that will be held. This concerns the extent to which the information provided by the applicant regarding personality data, such as the origin of personal life, whether the applicant is a generous person, his past circumstances, has ever been involved in the black list and as with information and references between banks, also needed.

b. Ability (Capacity)

What is meant is the ability to control, lead, master the field of business, seriousness and see future perspectives, so that in the end it will show the ability to repay the credit extended.

c. Capital (Capital)

Applicants are required to have their own capital and credit from the bank as an additional function. To see whether the use of capital is effective, look at the financial statements by taking measurements such as in terms of liquidity, solvalidity, profitability and it must also be seen from which sources of capital are currently available.

d. Guarantee (Collateral)

It is a guarantee given by prospective customers, both physical and nonphysical. The guarantee should exceed the amount of credit given and its legality must also be checked so that if a problem occurs, the guarantee deposited will be used as soon as possible.

e. Economic Condition (Condition of Economy)

In assessing credit, present and future economic and political conditions should also be assessed according to each sector, as well as the business prospects of the sector it is running. The assessment of the prospects for the business sector to be financed should have a really good prospect, so that the possibility of a credit problem is relatively small.

However, the bank did not use the fourth $C$ in this credit, namely Collateral because there was no collateral at all in the distribution of this credit and what was highlighted from the $5 \mathrm{C}$ was Character and Capacity to Repay. That is why in this case, the bank asks for the requirements for a Decree Appointment of Civil Servants to find out the job of the prospective debtor, and from the letter can then be assessed the ability to

${ }^{23}$ Ibid. 
repay based on the amount of credit to be disbursed and the principal salary of the prospective debtor based on class and rank $^{24}$.

\subsection{Implementation of Bank Credit Agreement with Warranty of Decree Appointment of Civil Servants}

Credit by the bank is executed by signing a credit agreement in the form determined by each bank. Bank as one of the largest and most trusted banks in Indonesia has provided credit to the public in various forms, including in the form of Mortgage Rights, Transfer of Property Rights to Trust/Fiduciary, Pawn (Pund), and Accounts Receivable, Transfer of Accounts Receivable (Cessie), Pawn for Pension/Allowances and Accounts Payable (Borghtocht).

Bank distributes consumptive loans to Civil Servants in the Palembang Regency government, where the Decree Appointment of Civil Servants is the guarantee. The basic considerations of Bank to provide credit with the inclusion of a Decree Appointment of Civil Servants as collateral in lending are: The Decree Appointment of Civil Servants is issued by the government agency where the civil servant works whose legality and integrity are undoubtedly a government institution; The Decree Appointment of Civil Servants is a guarantee of the Bank's confidence in the character of prospective debtors, especially Civil Servants as part of the 5C, namely the bank's assessment system for prospective debtors, and The relationship begins with the arrival of the customer at the Bank on working days and hours to provide complete credit requirements and fill in a Loan Application Form that can be taken right away at the office of Bank.

a. Submission of Files

The requirements that must be completed are:

1) Photo of Husband and Wife, size (4x6): 1 sheet (New Submission);

2) Copy of Husband and Wife's KTP: 2 sheets (New Application);

3) Photocopy of Family Composition Card (KSK): 1 sheet (New Application);

4) - SK./Decree First Appointment (Original) Civil Servant (CPNS) (80\%)

- SK. Genuine PNS (100\%)

- SK. Employee's Last Promotion (Original)

- Taspen Card (Original)

5) List of salary details for the last month made by the treasurer/clerk known to the supervisor/head of the service/agency;

6) A blank Kretap loan application can be taken at Bank;

7) Do not have similar loans at other banks;

8) The New Interest Rate Provisions.

\footnotetext{
${ }^{24}$ Alam, Bahrul., \& Khisni, Akhmad. (2020). Legal Protection of Holders of Land Loss Data In The City Land Office of Kendari. JURNAL AKTA: Vol.7, No. 2, 159-164. Retrieved from http://jurnal.unissula.ac.id/index.php/akta/article/view/7963
} 
Based on this, an agreement on a credit agreement can also be formulated outside the Bank between bank employees and customers/prospective debtors, for example non-formal meetings between customers and bank employees, however the implementation of agreements and administrative settlements must still be completed in the Bank. So in this way it is also not allowed if the loan agreement file is delivered and picked up by a bank employee at the customer's house. Customers who intend to apply for credit with the guarantee of a Decree Appointment of Civil Servants at Bank must fill out a blank.

A loan application containing a customer request for permanent credit, stating:

1) Agency information consisting of name of agency, line of business, address and telephone;

2) Applicant information, containing the identity of the credit applicant customer, namely name, address, place and date of birth, KTP/ID number, gender, nationality, residence status and length of stay, marital status, education, wife's name and occupation, other addresses that can be contacted in an emergency;

3) Job Information, containing position (class/rank), work unit, length of work, employee status, other jobs;

4) Attachment of data or documents that are included in accordance with the requirements requested by the Bank;

5) Information on the application and purpose for using credit, and the credit period;

6) Financial information from the applicant, namely regarding the fixed salary received per month, deductions from salary per month, net salary per month, expenses per month remaining salary per month, salary income per month.

From the things mentioned above, the credit applicant signs the form and states that:

1) All requirements and data and information that have been submitted are and are correct, and authorize Bank to obtain references from any source in a manner deemed appropriate by Bank;

2) Bank has the right to reject an application and is not obliged to provide reasons for rejection;

3) If credit is realized and later due to something intentionally or not, related parties in order loan settlement on behalf of the customer.

Other files that must also be included are as follows:

1) Debtor's Statement;

2) Agency Leader Recommendation Letter;

3) Power of Attorney to Cut Salary;

4) Statement Letter of Treasurers with Deductions in Services

b. On the Spot/Field survey 
Before distributing credit, the bank carries out a series of activities known as credit analysis. With these activities, it is hoped that an illustration can be obtained that credit is distributed to the right person. Thus the risk of bad credit or non-payment of credit can be reduced. Credit analysis can help banks to collect and find out information related to the willingness and ability of prospective debtors to repay borrowed loans. The more information the bank obtains about prospective debtors, the less uncertainty will be the element of credit disbursement.

Field inspection activities by observing the place where the civil servant is assigned is to verify the validity of the Appointment Decree and the place of residence to find out the truth of the applicant's identity and status. When going to do On the Spot, the bank does not notify the prospective debtor in accordance with the actual situation.

c. Credit Decision

The credit decision in this case is to determine whether credit will be given or refused, if accepted it will be prepared for the administration, the credit decision which will include:

1) Amount of money received;

2) Credit period;

3) Costs that must be paid.

Credit decisions issued by the leader of Bank immediately after receiving and paying attention to the report from the Account Officer and Credit Documentation Administration (ADK), taking into account whether or not someone can obtain credit from Bank. The manager of bank considers whether the prospective debtor meets the 5C (Character, Capacity, Capital, Condition of Economy, Collateral) requirements.

Character (character analysis), whether during observation as a customer he is considered to have good character or not. Capacity (ability analysis), whether the source of the customer's debtor's income is sufficient to repay the requested loan principal. Condition of Economy (analysis of business conditions and prospects), whether the work done by the customer is sufficient to pay back the loan principal and interest. Collateral (guarantee analysis), is the guarantee for the Appointment of Civil Servants sufficient to cover when compared to the credit that will be given.

If you pay attention to Bank has an assessment system for prospective debtors. As it is known that in every credit extension, consideration and caution is required so that trust, which is the main element in credit, is actually realized so that the credit given can hit its target and guarantees the repayment of the credit is timely according to the agreement ${ }^{25}$.

d. Credit Agreement Signing

This activity is a continuation of the decision on credit, so before the credit is disbursed, the prospective debtor first signs a credit agreement. At Bank has provided a credit agreement with a standard contract form and the contents

${ }^{25}$ Op.Cit. 
eISSN : 2581-2114, pISSN: 2406-9426

have been determined by Bank, the nature of the agreement is under hand because it is not attended by an authorized official, namely a Notary, the debtor only agrees and affixes his signature and affixes the blank application for a six thousand rupiah stamp duty. From the debtor application documents that have been signed by the debtor, Bank will be requested for approval (Warmerking) from the Notary.

e. Credit Realization

Realization of credit is given after signing the necessary documents by opening a savings account at Bank. The aim is to facilitate credit distribution to the debtor concerned.

f. Fund distribution or Fund Withdrawal

Disbursement or withdrawal of money from the debtor's account for this kind of credit is disbursed simultaneously by the bank and the withdrawal or withdrawal of funds is completely left to the debtor whether all at once or in stages according to the needs of the debtor.

In the credit agreement at Bank did not state that the Civil Servant Decree was a guarantee of credit because the agreement stated that the guarantee was all assets of the credit recipient, both movable and immovable, both existing and future. There will be a repayment of the credit amount later. This is different from the request for a Decree Appointment of Civil Servants at the time of filing the documents and the Decree Appointment of Civil Servants to be withheld by the bank when the credit agreement is signed.

The detention of the Decree Appointment of Civil Servants is only as a security measure for the credit, has no collateral value and the Decree will not be auctioned for debt settlement if the debtor in the future defaults. The Decree Appointment of Civil Servants guarantees the payment of the debt because it is based on the belief that the debtor is sufficient to guarantee the payment of the debt. Namely as a recommendation for the belief that the debtor is really a Civil Servant in Palembang Regency, after all, the nominal credit is not large or depends on the amount of the debtor's monthly salary and the possibility of default is very small.

The Decree Appointment of Civil Servants is not a guarantee on the collateral for this consumptive credit, only as a pressure on the debtor to pay off his debt. With the detention of the decree, the debtor will try to continue to pay off his debt and not damage his credibility as a Civil Servant.

\section{CLOSING}

\subsection{Conclusion}

Implementation of the Credit Agreement with the guarantee of a Decree Appointment of Civil Servants at Bank starts from filling out a blank/credit application form by prospective debtors which is followed by the bank conducting field research whether the debtor is really a civil servant according to the data written by the debtor and research on the candidate's ability debtor to pay off his debt. And it ends with the disbursement of credit funds by banks to debtors for the loan ceiling of $60 \%$ of the employee's net salary according to the class/rank owned by the customer/debtor. Form of credit agreement between Bank with prospective debtors (Civil Servants) is carried 
out with a deed under hand by fulfilling a stamp duty, where a legalization (warmerking) will be requested to the Notary.

\subsection{Suggestion}

Credit settlement with the guarantee of a Decree of Appointment of Civil Servants who defaults, namely the first holding of deliberations by inviting the debtor to fulfill the elements of good faith, if the debtor is naughty and does not immediately fulfill his obligation to pay off then a legal route will be taken, where this method is only used to provide emphasis (preasure) to the debtor to pay off the borrowed credit and the bank can withdraw the lawsuit. If the debtor moves/transfers, he will be asked to pay it by transferring funds between banks to Bank.

\section{References}

Journals:

Adigita, Monicha R., Ma'ruf, Umar., \& Witasari, Aryani. (2019). The Role and Protection of Laws to Notary Related To the Dispute That Made Between the Parties. JURNAL AKTA: Vol. 6, No. 4, 783-788. Retrieved from http://jurnal.unissula.ac.id/index.php/akta/article/view/7631

Alam, Bahrul., \& Khisni, Akhmad. (2020). Legal Protection of Holders of Land Loss Data In The City Land Office of Kendari. JURNAL AKTA: Vol.7, No. 2, 159-164. Retrieved from http://jurnal.unissula.ac.id/index.php/akta/article/view/7963

Arrohim, Mohammad B., \& Wahyuningsih, Sri Endah. (2020). Analysis of Judicial Application of Criminal Penalty Against Notary / Land Deed Officials Conducting Making Crime of the Fake Authentic Deed in State Court of Semarang. JURNAL AKTA: Vol.7, No. 2, 183-188. Retrieved from http://jurnal.unissula.ac.id/index.php/akta/article/view/7891

Chusna, Amalia., \& Hafidz, Jawade. (2019). The Role of the Notary in the Credit Agreement with Mortgage Guarantee (Case Study in the Bank Tabungan Negara (Persero) Tbk). JURNAL AKTA: Vol. 6, No. 4, 719-726. Retrieved from http://jurnal.unissula.ac.id/index.php/akta/article/view/7668

Ferdiyanti, M. Indah Verena., Purnawan, Amin., \& Soegiyanto. (2019). Setting the Effectiveness of Law Position and Code Notary to the Quality of Performance. JURNAL AKTA: Vol. 6, No. 4, 797-804. Retrieved from http://jurnal.unissula.ac.id/index.php/akta/article/view/7887

Fuditia, Megacaesa., \& Mashdurohatun, Anis. (2020). Protection Against Recipients Notary Deed That Allegedly Protocol To The Legal Issue In Semarang. JURNAL AKTA: Vol.7, No. 2, 177-182. Retrieved from http://jurnal.unissula.ac.id/index.php/akta/article/view/7888

Harjanto, Fery., \& Gunarto. (2018). Effects Of Creation Deed of Sale and Purchase of Land Which Does Not Match Procedure of Making Land Deeds. JURNAL AKTA: Vol. 5, No. 4, 857-864. Retrieved from http://jurnal.unissula.ac.id/index.php/akta/article/view/3718

Jaya, Hendro K., \& Purnawan, Amin. (2020). Review Of The Implementation Process Of Completion Of Juridical Code Violations Of Notary In Kendari. JURNAL 
eISSN : 2581-2114, pISSN: 2406-9426

AKTA: Vol.7, No. 2, 169-176. Retrieved from http://jurnal.unissula.ac.id/index.php/akta/article/view/7881

Nofita S., Putri, Chalim, Munsharif A., \& Setyawati. (2020). Legal Protection Against Substitute Notary in Semarang Based on Act No. 2 of 2014 Amendment Act No. 30 of 2004 concerning Notary. JURNAL AKTA: Vol.7, No. 2, 195-200. Retrieved from http://jurnal.unissula.ac.id/index.php/akta/article/view/7901

Saputri, Anindia I., \& Witasari, Aryani. (2020). Notary Role In Making The Deed Of Murabahah Financing On Islamic Bank (Review On Financing Agreement In Islamic Bank Of Central Java). JURNAL AKTA: Vol.7, No. 2, 229-236. Retrieved from http://jurnal.unissula.ac.id/index.php/akta/article/view/7874

Suciani, Fiana Z., \& Witasari, Aryani. (2018). Implementation Of Mudharaba Agreement In PT. Bank Tabungan Negara (BTN) Tbk. Sharia Business Unit (SBU) Branch Of Semarang. JURNAL AKTA: Vol. 5, No. 4, 865-870. Retrieved from http://jurnal.unissula.ac.id/index.php/akta/article/view/3721

Wahyuni, \& Ma'ruf, Umar. (2020). The function of the Notary / PPAT In filing process Acquisition of Land Rights To Interests Investment in Regional Autonomy Era Based on Act No. 25 of 2007 concerning Foreign Investment. JURNAL AKTA: Vol.7, No. 2, 189-194. Retrieved from http://jurnal.unissula.ac.id/index.php/akta/article/view/7965

Widyawati, \& Handoko, Widhi. (2018). The Notary Role / PPAT in Improving Legal Awareness Society to Perform Registration Rights to Land Based on Government Regulation No. 24 of 1997 on Land Registration. JURNAL AKTA: Vol. 5, No. 4, 975-980. Retrieved from http://jurnal.unissula.ac.id/index.php/akta/article/view/4127

Books:

Hadiri, Nawawi. (2002). Metode Penelitian Sosial. Yogyakarta: Gajah Mada University Press

Hasanuddin, Rahman. (1995). Aspek-aspek hukum Pemberian Kredit Perbankan di Indonesia. Bandung: Citra Aditya Bakti

Iswardono. (1999). Uang dan Bank. Yogyakarta: Liberty

J, Satriyo. (1993). Hukum Jaminan, Hak-hak Jaminan Kebendaan. Bandung: Cira Aditya Bakti

Moleong., Lexy. J. (2005). Metodologi Penelitian Kualitatif Edisi Revisi. Jakarta: PT Remaja Rosdakarya

Putra, Edy. (1986). Kredit Perbankan Suatu Tijauan Yuridis. Yogyakarta: Liberty

Regulations:

1945 Constitution

Civil Code

Act No. 7 of 1992 concerning Banking

Internet: 
eISSN : 2581-2114, pISSN: 2406-9426

Kebiasaan Ngutang di Kalangan PNS. Suara Merdeka: http://Suara Merdeka Cybernews.com, accessed on 17 July 2020. 